\title{
Rainfall Distribution over Ghana: The Effect of Distance from the Sea
}

\author{
Boateng, G., Asuah, M. G., Kyeremeh, E., Otoo, K. A., \& Otoo, E.A \\ Berekum College of Education, Berekum, Ghana
}

\begin{abstract}
Rainfall is a major determinant of agricultural production in any agro-ecological zone across the world. Its seasonal and annual characteristics such as onset and intraseasonal rainfall distributions are characterized by marked fluctuations which pose a lot of challenge to forecast. Access and uptake of seasonal and intra-seasonal forecasts is crucial in decision making among all stakeholders especially the farmer whose activities is greatly influenced by rainfall onset and distribution. This study sought to analyse the extent to which distance from the sea (source of moisture) influence rainfall distribution in the country in time and in space. The data for the study was obtained from GMeT from 1982 -2012. The thirty-oneyear data from twenty-two rainfall stations (synoptic) were used to derive the mean averages and simple linear regression. The study concluded statistically that distance from the sea has no effect on rainfall distribution in the country. It was therefore recommended that a combination of factors could be considered to actually understand the driving force of rainfall amount that actually occurs at a particular location within the country.
\end{abstract}

Key words: rainfall, distance from the sea, synoptic stations, south west monsoons

\section{INTRODUCTION}

$\mathrm{R}$ ainfall is a major determinant of agricultural production in any agro-ecological zone anywhere in the world. Its seasonal and annual characteristics such as the onset and intraseasonal rainfall distribution that promote good crop yields are, however, characterized by marked fluctuations. For instance in Puerto Rico lower soil water content and increases in the relative crop yield reduction were associated with increasing rainfall deficits mostly in the dry seasons (Harmsen, Miller, Schlegel, \&Gonzalez, 2009). In Ecuador, rainfall is characterised by short, frequent low volumes. A strong daily variation exist with most rainfall occurring in the afternoon. There is considerable rainfall variation between the wet and dry seasons with a difference of $100 \mathrm{~mm}$. A remarkable spatial variation in rainfall distribution exist at distances of less than $4000 \mathrm{~m}$. Average daily rainfall within this range differs more than 25\%. (Buytaert, Celleri, Willems, De Bie`vre, \& Wyseure, 2006). Several studies have reported variability in rainfall across Africa. In Ethiopia, annual rainfall varies from about $770 \mathrm{~mm}$ in Lalibela, the eastern part to $>1660 \mathrm{~mm}$ in Chagni, western part. Between the periods of 1975-2003 different trends were observed across different locations. Annual and kiremt rainfall showed significant increasing trends in Dessie and Lalibela. A decreasing kiremt rainfal trend occurred in Debre Tabor and decreasing belg rainfall in Dangla (Bewketa and Conway, 2007). These fluctuations are not easy to forecast, yet knowledge will help the farmer to plan his farming activities strategically. Rainfall variability has serious implication on food production and livelihood in developing regions such as West Africa where irrigation is limited and inter-annual and multi-decadal variability occurs particularly when associated with declining rainfall total. The situation is exacerbated by the fact that more than half the population in the sub-region is directly engaged in predominantly rain-fed agriculture.

In Ghana, rainfall has been one of the most frequently discussed climatic element. This is probably due to the fact that this element determines the agricultural calendar, and that it also determines the success or failure and the production of crops, pasture and even life and death of flora and fauna (Hayward \& Oguntoyinbo, 1987). Ghana, like the other parts of the sub-continent, has undergone a period of declining annual rainfall total in addition to a shifting regime since the early 1970s and is only showing signs of recovery since 2000 (Owusu, Waylen \& Qui 2008). The Ghanaian economy in general and food supply specifically are highly dependent on agricultural production. Agriculture provides the major source of income and livelihoods for a large portion of the population, and about $17-50 \%$ of Gross Domestic Product (GDP) in some West African countries and Ghana as well (Owusu, Waylen \& Qui 2008). However, agriculture is heavily dependent on rainfall, with the seasonal characteristics of rainfall (Sultan, \& Janicot, 2003) being the primary factor. The onset of rainfall is very crucial to farmers as it answers the vital question "when to plant?" Adiku \& Kuatsinu (1992). Crop production in Ghana is largely rain-fed with only $0.08 \%$ of the country's agricultural land under irrigation. Agriculture accounts for $35 \%$ of the Gross Domestic Product of Ghana (Ministry of Finance, 2007), therefore, research on rainfall patterns in all of the country's agroecological zones becomes imperative for successful economic planning. This includes studies on causes, amount and distribution of rainfall over Ghana in space and time. Studies on rainfall over Ghana have traditionally been concerned with the efforts to explain the temporal and spatial rainfall anomalies and deficiencies only along the coast in terms of the nature of the coast and some upwellings of cold waters off the coast of Accra (Acheampong, 1982). There seems to be little or no research on distance from the sea and rainfall distribution in Ghana as a whole. The study therefore examined the influence of distance from the sea on rainfall distribution in Ghana. The study established that rainfall affects mans' activities in so many 
ways and as such, designs of storm water management, telecommunication, erosion and sediment control are highly dependent on rainfall characteristics. High intensity rainfall, particularly if sustained over a long period of time, is mostly responsible for altering the morphology of watersheds and therefore, knowledge of the distribution of rainfall intensity is important in the design of erosion control and runoff conveyance systems. The study sought to analyze rainfall distribution over Ghana and to determine the extent to which distance from the sea influences rainfall with variation in distance. It was hypothesized that, there is no significant relationship between distance from the sea and the amount of rainfall an area receives in Ghana.

\section{Overview of Rainfall variability over Ghana}

Literature on rainfall in Ghana, has concentrated on selected regions. Only few attempts have been made to do a cross-zonal comparsion (Adiku, Atika, Laryea, Mawunya \& Yangyuoru, 2011). Adiku et al. (2011) observed that the risk of dry spell is higher in both the major and minor seasons in the south (Accra), than in the north (Tamale), which only experiences a single rainy season. The national study undertaken by Opoku-Ankomah and Cordery (1994) revealed that rainfall distribution in the three southern zones is different from the northern zone. They attributed this to the movement of the ITCZ and the influence of Atlantic SSTs. Although considerable attention has been devoted to the relationship between the Sahel rainfall and SSTs, little attention has been given to the relationships between SSTs and rainfall of the rest of West Africa particularly to the Ghanaian rainfall (Opoku - Ankomah \& Cordery, 1994).

Quoting the earlier work of Boateng (1966), OpokuAnkomah and Cordey (1994) advised that rainfall variability in most parts of Ghana should be viewed differently from that of the Sahel since the latter receives its maximum rainfall in the period between July and September, a period when southern parts of Ghana are drier. Nonetheless annual rainfall has been following downward trend throughout Ghana, between 1935 and 1990 (Adiku \& Stone, 1995). In his interim report on ENSO and seasonal rainfall variability in Eastern Ghana, Adiku et al (2011), highlighted the downward trends pointing out that of the total of 10 droughts experienced in Accra in the 54 years between 1935 and 1989, three occurred in the 1980's, and only five in the first 35 years. With regard to ENSO and rainfall variability in southern Ghana, Adiku et al (2011) made two observations: Seasonal rainfall totals were higher during La Nina periods, and Neutral during October, November and December (OND); rainfall declined in EI Nino phase in the subsequent rainy season. While there is little difference in annual rainfall total when La Nina and neutral events preceding the rainy season, EI Nino events produce significantly lower subsequent rainfall. Secondly, Adiku et al (2011) link the decline in the number of rainy days in the months of April and July (the beginning and end of the major rainy season in his study areas) to EI Nino events. Estimates of difference in seasonal rainfall between a neutral and severe
EI Nino years are, at least, $130 \mathrm{~mm}$, which is significant for plant growth and productivity.

The available literature on Ghana rainfall distribution points to a reduction in rainfall in the last two decades of the period in most parts of the country. The factors responsible for seasonal and inter-annual variability are complex, multifaceted, and operate at various frequencies and time scales. The exact nature of the impact varies from the humid south to the dry zone of northern Ghana, according to as the fluctuations in the principal rain producer - the ITCZ over Ghana (Adiku \& Stone, 1995).

Several authors on the geography of West Africa have commented on the rainfall variability and its effect along the coast of Ghana. Among these are Knox (1915) and Boateng (1966) who observed that from the western frontier as far as Cape Three Points, the coast receives the full effect of the onshore southwest monsoon winds, but thence eastwards, the coast bends up northwards and the winds are generally parallel with the coast which consequently does not receive as much precipitation (Acheampong, 1982). In another work, Fitzgerald (1950) observed that the highest rainfall occurs where the coast is approximately at right angles to the path of the south-westerlies and the hinterland is of elevated altitude. Walker (1957), Chen (2006) and Wise (1944), associated the variability of rainfall along the coast of Ghana to some Cold off-shore bodies of water which restrict convectional rainfall. There has been the general belief that there are cold ocean waters off the coast of Accra caused possibly by (a) upwelling of cold water, (b) the cold oceanic waters brought on to the continental shelf by the predominantly west to east Guinea current, and that at certain times this current is reflected by Cape Palm and Cape Three Points to initiate the seasonal upwelling (Acheampong, 1982).

The idea that the coastal alignment east of Cape Three Points has a major effect on the rainfall distribution has not been accepted easily since not all rain-bearing winds are south-westerly. Moreover, other parts of the Guinea coast, for example Tabou, are in the same way aligned as the coast of Accra, yet they are not so dry (Acheampong, 1982). We cannot also accept the argument that the cold off-shore waters are the causes of the rainfall variations along the coast of Ghana. Acheampong (1982) has shown that the so called cold off-shore currents have little or no effect on the coastal temperatures, let alone on the amount of rainfall over the coast. It is however true that cool or cold ocean current can cause fogs thick enough to produce light drizzle in low latitudes where the coasts are backed by hills (Flohn, 1969).

Apart from meteorological circumstances the distribution of rainfall over Ghana, both in time and in space, reflects not only circumstances peculiar to that territory itself but also those typical of West Africa as a whole. The location and the physiographic nature of the country intensify, and at time weaken weather phenomena and rainfall producing mechanisms that also occur in other areas (Walker, 1957 \& Gregory, 1965). These phenomena and mechanisms are 
intimately related to the inter-actions between the dynamic sub-tropical anticyclone over the Sahara and its counterpart south of West Africa over the Atlantic Ocean, and they are reflected in the distribution and characteristics of the basically easterly and westerly airstream that owe their origins to these high-pressure systems (Pedelaborde, 1958). The relationship between monthly rainfall and distance from the sea for the two groups of gauges was also evident, but less marked. In most months and for both groups of gauges, monthly rainfall decreased as distance from the sea increased. Decreases in rainfall with distance were greatest in the wetter months of June to September, and were not dissimilar in magnitude in the two groups of gauges; however, decreases in rainfall in these months appeared to be less spatially variable in the case of rain-shadow gauges, and in consequence the decreases were statistically significant whilst those of ocean-facing gauges, on average, were not. Statistical analysis of mean monthly rainfall measured by 31 gauges in the Freetown Peninsula shows clear differences between those facing the south-westerly monsoon and those in the peninsular rainshadow (Hayward \& Clarke, 1996).

Distance from the sea is a factor in the overall climate due to ocean currents, which are caused by the winds that blow over the surface of the ocean. Most of the moisture in the air comes from evaporation from the sea surface. Thus as the air mass blows from the sea over land (and is pushed up and cooled as it does so) the moisture will come out of the air as rain. The further the air moves inland the more moisture it will have lost and the drier it will become (Dadson 2016). This means that hinterland areas get less rain on average than coastal regions. Similarity, it is also established that generally, the amount of precipitation decreases moving away from the equator. This is mainly due to the fact that other factors being constant, warmer air is capable of carrying more moisture and therefore will have a greater potential to cause precipitation. The influence of the South West Monsoons (SWM) from the Atlantic Ocean as a rain-producer, decreases as their ocean source of moisture is left behind (Gregory, 1965). Rainfall decrease inland from the sea except for the Accra plains or the south east coast of Ghana where rainfall amount ranges from $725 \mathrm{~mm}$ to $875 \mathrm{~mm}$. In the south-western corner of Ghana, the mean annual rainfall is about $2000 \mathrm{~mm}$ inland. Kumasi records about $1500 \mathrm{~mm}$ of rainfall annually. This decreases to about $1000 \mathrm{~mm}$ near Bawku which is further away from the sea than Kumasi (Dickson \& Benneh 1988). According to Hayward and Clarke (1996), the relationship between the monthly rainfall and the distance from the sea is evident, in that, the monthly rainfall decreases as distance from the sea increases.

\section{The study area}

Ghana is located between latitudes $4^{0} 5^{\prime} \mathrm{N}$ and $11^{0} 5^{\circ} \mathrm{N}$, and longitudes $1^{0} 12^{\prime} \mathrm{E}$ and $3^{0} 15^{\prime} \mathrm{W}$. The country covers an area of $238,539 \mathrm{~km}^{2}$ (EPA, 2000). The climate of Ghana is generally warm humid and tropical in nature (Dadson, 2019). The north has only one rainy season from April to September, while two rainy seasons occur from April to July and from September to November in the southern parts of the country. The seasonality in the rainfall patterns in Ghana is brought about by the movement of the Inter-Tropical Convergence Zone (ITCZ). Annual rainfall ranges from 1,100 millimeters (Navrongo) in the north to $2,100 \mathrm{~mm}$ (Axim) in the southwestern part of the country. The annual mean relative humidity is $44 \%$ and $80 \%$ in the north and south respectively (Dickson \& Benneh, 1988). Temperatures in the country vary with seasons and elevation. In most areas, the highest and lowest temperatures occur in March and August, respectively. Mean annual temperatures are between twenty $21^{\circ} \mathrm{C}$ and $35^{\circ} \mathrm{C}$ respectively (VIGS, Ghana, 2013).

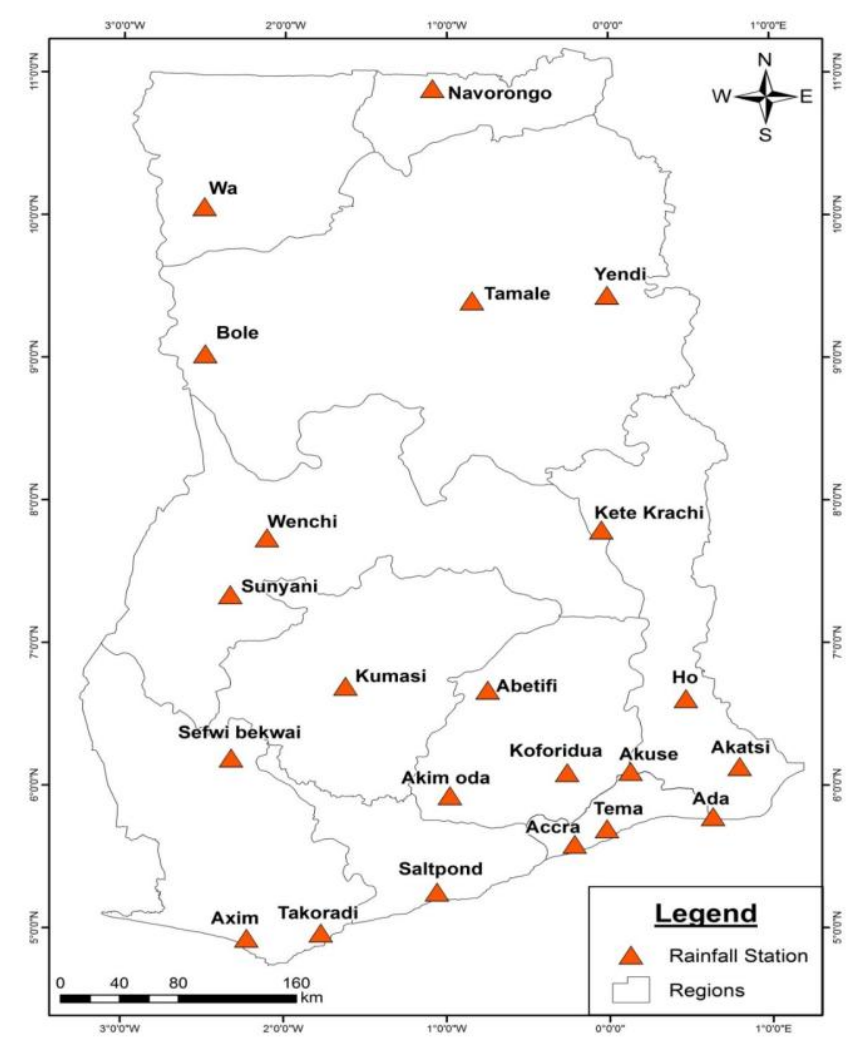

Figure 1: Map of synoptic stations

Source: Cartography Unit of DGRP, UCC

\section{MATERIALS AND METHODS}

Rainfall data from the 22 synoptic stations employed in this research were collected from the Ghana Meteorological Agency (GMet) in Accra where all Meteorological records are kept. Various weather reports as well as weather charts were also collected. Accra, Tema, Ada, Akuse, Akim Oda, Abetifi, Saltpond, Takoradi, Sefwi Bekwai, Kumasi, Kete Krachi, Ho, Navrongo, Wa, Yendi, Tamale, Wenchi, Sunyani, Akatsi, Axim and Koforidua, are the synoptic stations. These stations were used because they have up-to date data, on all the rainfall values for the period under consideration. The types of weather records are explained below: 
Hyetograph: this was the original daily rainfall chart obtained from the self-recording raingauge. A black continuous or broken line on this chart gave both the amount and the duration of rainfall recorded during a particular period.

The daily weather (MET 100 and 101): This file provided the statistical summary of the weather at each station as well as for given synoptic hours for each day of the month.

The summary of daily weather: Contained the synoptic weather situation for the whole of West Africa with particular reference to Ghana and its surrounding areas for each day of the month.

The monthly report of work: This provided the monthly summary of the weather.

The annual summary of observations in Ghana: Gave the statistical summary of the weather elements at all the stations for each month of the year.

The Kalamazoo: Was the register which contained the rainfall data for each day of the month.

A regression analysis (Equation 1) was performed to ascertain the relationship between distance from the sea and rainfall. In using this method, it was assumed that there is a linkage between the two parameters

$\mathrm{Y}=\alpha_{0}+\alpha_{1} \mathrm{~h}_{1}+\varepsilon$

where $\mathrm{Y}$ is rainfall,

$\alpha_{\mathrm{o}}$ is intercept,

$\alpha_{1}$ is the coefficient of distance from the sea,

$\mathrm{h}_{1}$ is the distance from the sea, and $\mathcal{E}$ is error term.

Source: Derived from Rainfall data

The study used descriptive design. Descriptive research design is a scientific method which involves observing and describing the situation of a subject without influencing it in any way. Neuman (2003) views descriptive design as representing "a picture of specific details of a situation, social setting or relationship". Descriptive designs are employed to gain more information about a particular characteristic within a particular field of study. The study adopted both quantitative and qualitative approaches. The study employed descriptive (qualitative) statistical tools to show trends in rainfall pattern between the periods 1982 and 2012 A simple regression analysis of the annual totals from all the 22 synoptic rainfall stations were plotted against their distances from the sea is shown in Figure 2.

\section{RESULTS AND DISCUSSION}

The study examined how distance from the sea which is the source of moisture affects the amount of rainfall an area in Ghana receives. The study was on the hypothesis that, there is no relationship between distance from the sea and the amount of rainfall an area receives in Ghana. Many authors have reported that, the closer an area is to the sea or water bodies the more the amount of rainfall received as compared to areas far from the sea. For example, Gregory (1965) asserted that the influence of the South West Monsoon Winds (SWM) from the ocean as the rain producer decreases as their ocean source is left behind. Hayward and Clark (1966) have also shown in West Africa that, there is evidence between distance from the sea and rainfall amount.

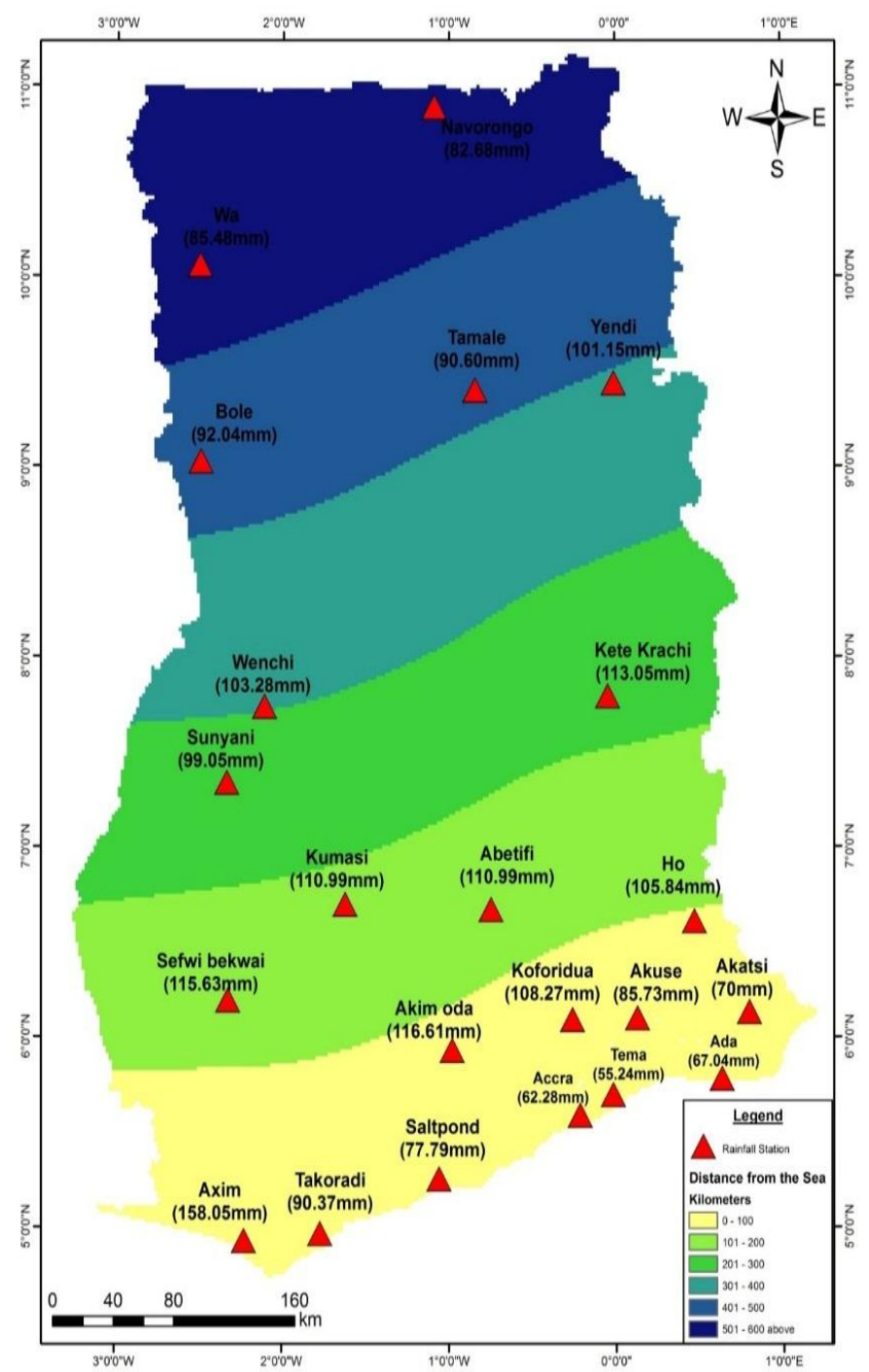

Figure 2: A map of Ghana showing the relationship between rainfall and distance from the sea Source: Cartography Unit of DGRP, UCC

That is, the relationship between monthly rainfall and distance from sea was evident in that, monthly rainfall decreases as distance from the sea increases. Dickson and Benneh (1988) stated that rainfall decrease inland from the sea except for the Accra belts and south east coastal plains of Ghana where rainfall amount from 725 millimeters to 875 $\mathrm{mm}$. In the south-western corner of Ghana, rainfall is about 2000 millimeters annually (Dickson \& Benneh, 1988). Also, Kumasi records an amount 1500 millimeters rainfall annually. The difference in rainfall amount is due to distance in relation 
to the sea or ocean which is the source of moisture. But the findings of the analysis with regards to the relationship between mean annual rainfall and distance from the sea deviate from what is postulated by certain authors. Authors such as Gregory (1965) and Hayward and Clark (1966) suggests that, the closer the area is to the sea, the higher the amount of rainfall, the findings from this study indicates that, distance from the sea has little impact on rainfall distribution statistically. Akuse, for example, has a standard error of 0.00003 which is smaller than the actual coefficient for distance from the sea which is the source of moisture $(-2.2)$

From Figure 3, there is no relationship between distance from the sea and rainfall distribution in the country. That is, distance from the sea has no effect on rainfall amount an area receives over the country. Except for Axim which is just at the coast, rainfall amount can even be higher in the interior (Figure 2). The Accra plains that is south-east coastal plains of Ghana, receives the lowest amount of rainfall in Ghana even though is very close to the sea. The possible reasons for this deviation and for the case of Accra can be linked to Acheampong (1982), That there has been the general belief that there are cold ocean waters off the coast of Accra caused possibly by (a) upwelling of cold water, (b) the cold oceanic waters brought on to the continental shelf by the predominantly west to east Guinea current, and that at certain times this current is reflected by Cape Palm and Cape Three Points to initiate the seasonal upwelling. In addition, there is the likelihood that, the amount, duration and intensity of rainfall in an area cannot be dependent on just a single factor but multiple ones as the case is in Ghana.

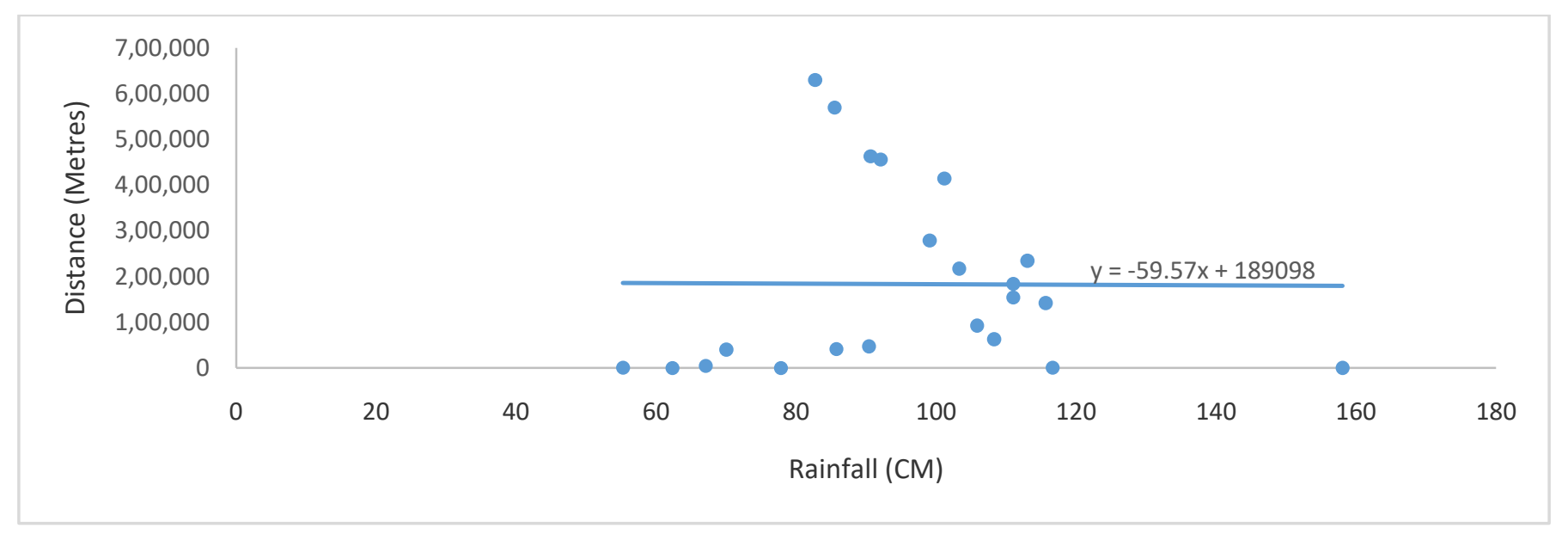

Figure 3: Relationship between mean rainfall and distance from the sea

It was also noted that, the normal distribution of rainfall in terms of space were accurate (Most of the moisture in the air comes from evaporation from the sea surface. Thus as the air mass blows from the sea over land (and is pushed up and cooled as it does so) the moisture will come out of the air as rain (Dadson, 2016). The further the air moves inland, the more moisture it will have lost and the drier it will become. This means that hinterland areas get less rain on average than coastal regions) but the deviation was observed mostly in the south eastern coast of the country such as Accra, Ada, and Tema. The other areas that had the deviations might have been influenced by other factors such as altitude as in the case of Abetifi, Koforidu, and Kete-Krachi. Vegetation (Land cover), wind direction and other anthropogenic factors (such as farming, lumbering, charcoal burning and settlement) can account for this occurrence. The simple regression analysis of the annual totals from all the 22 synoptic rainfall stations were plotted against their distances from the sea as shown in Figure 3. It was observed from Figure 3 that there is a negative or inverse relationship between rainfall and distance from the sea. Since the coefficient of determination is negative (0.00076), there is a negative (or inverse) relationship between the variables. Thus, the observation is that places far away from the sea are likely to experience less rainfall than places closer to the sea. The implication is that distance from the sea has little influence on the rainfall distribution over Ghana. It is also inferred from the result that, there may be other related factors which may have accounted for the observed result.

\section{CONCLUSION}

Many authors have proved that, the closer the area is to the sea or water bodies the more the amount of rainfall received as compared to areas far from the sea. For example, Gregory (1965) asserted that the influence of the South West Monsoon Winds (SWM) from the ocean as the rain producer decreases as their ocean source is left behind. He also asserted that in West Africa, there is evidence between distance from the sea and rainfall amount. That is the relationship between monthly rainfall and distance from sea was evident in that, monthly rainfall decreases as distance from the sea increases (Gregory 1965). Dickson and Benneh (1988) stated that rainfall decrease inland from the sea except for the Accra belts and south east coastal plains of Ghana where rainfall amount ranges from 725 millimeters to $875 \mathrm{~mm}$. In the south-western corner of Ghana, rainfall is about 2000 millimeters annually. Also, Kumasi records an amount 1,500 millimeters rainfall 
annually. The difference in rainfall amount is due to distance in relation to the sea or ocean which is the source of moisture.

Notwithstanding these, this study concludes that rainfall distribution in Ghana is in no way influenced by distance from the sea which is the source of moisture. For example, to the east of Cape Three Points, rainfall decrease along the coast and some distance inland. Rainfall decreases inland due to evaporated air from the sea blowing up the hill and cooling in the process. As the clouds move further inland, they lose moisture. There are therefore other factors, both meteorological and terrestrial, primary and secondary that could influence rainfall distribution in Ghana rather than moisture inflow mainly from the ocean.

\section{REFERENCES}

[1] Acheampong, P.K. (1982). Rainfall anomaly along the coast of Ghana: Its nature and causes. Geographiska Annaler 64 A (1982)3-4.

[2] Adiku, S. G. K. \& Kuatsinu, E. K. (1992). Rainfall analysis for effective planning of crop production under rainfed conditions in three farming zones of Ghana. Proceedings of Soil Science Society of Ghana, Vol. 12 \&13, pp 145-154.

[3] Adiku, S. G. K. \& Stone, R. C. (1995). Using the Southern Oscillation index for improving rainfall prediction and agricultural water management in Ghana. Agric. Wat. Mgmt 29: 85-100

[4] Adiku, S. G. K., Atika, E., Laryea, K. B., Mawunya, F. D. \& Yangyuoru, M. (2011). Characterisation of seasonal rainfall for cropping schedules. West African Journal of Applied Ecology, 19(1).

[5] Bewketa, W \& Conway, B (2007). A note on the temporal and spatial variability of rainfall in the drought-prone Amhara region of Ethiopia, International Journal of Climatology, 27: pp14671477

[6] Boateng, E. A. (1966). A Geography of Ghana, Cambridge, pgs. 31-33

[7] Chen, T. C. (2006). Characteristics of African easterly waves depicted by ECMWF reanalyses for 1991-2002. Mon. Wea. Rev., 134, 3539-3566.

[8] Buytaert, W., Celleri, R., Willems, R., De Bie`vre, B., \& Wyseure, G. (2006). Spatial and temporal rainfall variability in mountainous areas: A case study from the south Ecuadorian Andes, Journal of Hydrology, vol. 329, issue 3-4, pp. 413-421
[9] Dadson I. Y. (2019). Understanding climatology. Cape Coast: University of Cape Coast Press

[10] Dickson, K.B. \& Benneh, G. (1988). A new geography of Ghana. Essex: Longman

[11] EPA. (2000). Climate change vulnerability and adaptation assessment of coastal Zone of Ghana. Final report. Accra: Ministry of Environment Science and Technology.

[12] Fitzgerald, W. (1950). Africa a Social Economic and Political Geography of its major Regions. Longman: 36-39.

[13] Flohn, H., (1969). Climate and Weather. New York.

[14] Gregory, S. (1965). Rainfall over Sierra Leone. Department of Geography, University of Liverpool Research Paper 2: 10-11; 2730.

[15] Harmsen, E. W., Miller, N.L., Schlegel, N.J., Gonzalez, J.E. (2009). Seasonal climate change impacts on evapotranspiration, precipitation deficit and crop yield in Puerto Rico, Agricultural Water Management, 96, pp.1085-1095

[16] Hayward, D. \& Oguntoyinbo J. (1987). Climatology of West Africa. Hutchinson, London.

[17] Hayward, D. \& Clarke, R.T. (1996). Relationship between Rainfall, Altitude and Distance From The Sea in the Freetown Peninsula, Sierra Leone. Hydrological Sciences Journal, 41:3, 377-384, Doi: 10.1080/02626669609491509.

[18] Knox, A. (1915). The Climate of the Continent of Africa, Cambridge

[19] Ministry of Finance (2007). 2008 National Budget. Ministry of Finance, Accra, Ghana.

[20] Ministry of Food \& Agriculture, Ghana. (2007). Food and agriculture sector development policy. Accra, Ghana: Ghana Government Policy Document.

[21] Opoku-Ankomah, Y. \& Cordrey, I. (1994). Atlantic sea surface temperatures and rainfall variability in Ghana. J Clim 7:551-558

[22] Owusu, K, Waylen, P, \& Qui, Y. (2008). Changing rainfall inputs in the Voltabasin: implications for water sharing in Ghana. GeoJournal 71:201-210

[23] Pedelaborde, P. (1958). The Monsoons, Paris

[24] Sultan, B, \& Janicot S. (2003). The West African Monsoon Dynamics Part II: Preonset and Onset of the Summer Monsoon. Journal of Climate 16(21):3407\{3427.

[25] VIGS, (2013). Ghana Website (online). Available http://www.africacalling.org/

[26] Wise, C. G. (1944). Climatic Anomalies on Accra Plains, Accra: 35-38.

[27] Walker, H. O. (1957). Weather and Climate of Ghana, Ghana Meteorological Department Note 5: 7-15. 


\section{Appendix}

Table 1

Regression Statistics

Multiple R 0.006732

R Square $\quad 4.53 \mathrm{E}-05$

Adjusted $\quad \mathrm{R}$

Square $\quad-0.04995$

Standard Error $\quad 23.28591$

Observations 22

ANOVA

\begin{tabular}{|c|c|c|c|c|c|c|c|c|}
\hline & $\overline{D f}$ & $S S$ & $M S$ & $F$ & Significance $F$ & & & \\
\hline Regression & 1 & 0.491554 & 0.491554161 & 0.000906536 & 0.976278772 & & & \\
\hline Residual & 20 & 10844.67 & 542.233712 & & & & & \\
\hline \multirow[t]{2}{*}{ Total } & 21 & 10845.17 & & & & & & \\
\hline & Coefficients & $\begin{array}{l}\text { Standard } \\
\text { Error }\end{array}$ & $t$ Stat & $P$-value & Lower 95\% & $\begin{array}{l}\text { Upper } \\
95 \%\end{array}$ & $\begin{array}{l}\text { Lower } \\
95.0 \%\end{array}$ & $\begin{array}{l}\text { Upper } \\
95.0 \%\end{array}$ \\
\hline Intercept & 95.69557 & 6.791758 & 14.089956 & $7.58795 \mathrm{E}-12$ & 81.52821467 & 109.8629 & 81.52821 & 109.8629 \\
\hline $\mathrm{X}$ Variable 1 & -0.00076 & 0.025271 & -0.03010873 & 0.976278772 & -0.05347426 & 0.051953 & -0.05347 & 0.051953 \\
\hline
\end{tabular}

